\title{
STATE SYSTEM GUARANTEES: THEORETICAL AND LEGAL CHARACTERISTICS
}

\section{Larysa Nalyvaiko}

\section{INTRODUCTION}

In the legal literature, more and more attention is paid to state system. The formation of a modern state system necessitates a scientific search in the field of guarantee in order to ensure its adequacy to the realities and prospects of socio-political development. At present, there is no comprehensive substantiated approach to defining the concept, features, classification criteria and types of state system guarantees.

Thematic actualization is related to the fact that the formation of the rule of law and civil society in Ukraine is directly related to the problem of creating a system of effective state system guarantees, the solution of which is based on the development and application of beneficial conditions, techniques and mechanisms for their implementation in public relations. After all, no matter what high authority the norms which fix the state system have, possessing a priority position not only in the Constitution, but in the whole system of legislation of Ukraine, they have to be effectively implemented in actual social relations. Creating an independent, constitutional and social state with a democratic system of government is a paramount task on the path to stability, and having effective guarantees is a prerequisite for its existence.

The state system guaranteeing is actualized by the need to improve the activity of the state as a whole and of separate bodies of state power which are intended to ensure the stability of its basic principles and institutions. The existence of a system of state system guarantees is a mandatory consequence of the existence and formation of a certain type of state system. In the absence of state system guarantees, the possibility of considering it as a functionally and structurally stable, political and legal phenomenon is lost.

\section{The concept and features of state system guarantees}

In jurisprudence, there is hardly another category that is so commonly used and, at the same time, has such a broad semantic form which contains a wide variety of meanings. This category is guarantees. In some cases we are talking about guarantees of legality, in others - about legality as a guarantee, about guarantees of the constitutional order, about guarantees of law and order, about law enforcement guarantees and law enforcement as a guarantee, 
about guarantees of the rights and freedoms of citizens and about the rights of a person as a guarantee of his freedom, etc.

Generally, the guarantee is an ideal model according to which the legal and factual status of a particular state as a whole should be shaped.

Guarantees are one of the main issues in the problem of the correct application of legal norms, the assurance of legality and many other processes of legal validity. The concept of guarantee is quite widely used in various spheres of human activity, in politics, philosophy, diplomacy, as well as in everyday, non-professional word usage ${ }^{1}$.

Studies of individual theoretical aspects of the state system and elements of the system of its guarantees were carried out by domestic and foreign scientists: M. Abdulaiev, N. Bobrova, M. Vitruk, T. Zavorotchenko, A. Kolodii, V. Kopieichikov, V. Korelskyi, V. Kotiuk, I. Magnovskyi, M. Marchenko, O. Mickiewicz, O. Negodchenko, M. Orzikh, V. Perevalov, V. Pogorilko, A. Polianskyi, Zh. Pustovit, Yu. Sokolenko, M. Stavniichuk, E. Supruniuk, V. Tatsii, Yu. Todiuk, O. Fritskyi, V. Shapoval, Yu. Shemshuchenko, Yu. Shymin and others.

Humanity has always sought to create a system of democracy that would truly be democratic and would protect their rights and freedoms, and without a credible mechanism of guarantee this would seem impossible. For a long time, scientists have sought to show at the theoretical level the need to create legitimate social institutions that should guarantee the existence of a democratic state system.

From the legal and technical side, the guarantee can be described as the proper activity of the subjects of law for the purpose of realization, actualization of certain social interest provided by legal protection. In such a context, the state of guaranteeing is determined by certain positive activities of the subjects of law, and in case of a breach of the balance of their interests, by the need for the use of instruments of legal protection and legal responsibility ${ }^{2}$.

In the theory of state and law, under "guarantees" some scholars understand the system of conditions, means and methods that provide each and every level of opportunity ${ }^{3}$. Others define "guarantees of democracy" as objective conditions and means that ensure not only the proclamation and

${ }^{1}$ Nalyvajko L.R. (2005) Gharantiji derzhavnogho ladu Ukrajiny: problemy vyznachennja ponjattja [State system of Ukraine guarantees: problems of definition of the concept]. Naukovyj visnyk Jurydychnoji akademiji Ministerstva vnutrishnikh sprav, no. 4 (24), pp. 153-159.

${ }^{2}$ Nalyvajko L.R. (2009) Derzhavnyj lad Ukrajiny: teoretyko-pravova modelj [State system of Ukraine: theoretical and legal model]: monoghrafija. Kharkiv: Pravo.

3 Korel'skiy V.M., Perevalov V.D. (1998) Teoriya gosudarstva i prava [Theory of Government and Rights]: uchebnik. Moskva: Infra-M, P. 504. 
legal consolidation of democratic principles, ideas, rights and freedoms of citizens, but also their comprehensive protection and implementation ${ }^{4}$. P. Rabinovych believes that the "guarantees of legality" are a system of means by which legitimacy is introduced, protected and, in the event of a breach, established in public life. In its turn, the scientist defines "legal guarantees of legality" as special means of introduction, protection and, in case of violation, restoration of legality ${ }^{5}$.

In modern science, from the standpoint of reflecting the guarantees of the rights and freedoms of man and citizen in the political and legal thought, I. Magnovskyi examines the ideas of Ukrainian scientists of the late $19^{\text {th }}-$ the first half of the $20^{\text {th }}$ century (M. Drahomanov, M. Kovalevskyi) on guaranteeing human rights ${ }^{6}$. V. Kotiuk explores "the guarantees of human and citizen rights and freedoms" as conditions, means and methods that ensure the comprehensive protection of the rights and freedoms of the individual ${ }^{7}$. $\mathrm{Yu}$. Oborotov believes that the decisive principle of forming a system of legal guarantees of rights and freedoms is the universality of their provision in all ways that are not contrary to the law. At the same time, among the legal guarantees of rights and freedoms $\mathrm{Yu}$. Oborotov distinguishes the guarantees of implementation and guarantees of protection ${ }^{8}$. In the Legal Encyclopedia S. Lysenkov, A. Taranov define guarantees of human and citizen rights and freedoms as conditions, means, ways that ensure full and complete protection of the rights and freedoms of a person ${ }^{9}$. In this context, the notion of guarantees encompasses the totality of objective and subjective factors aimed at the practical realization of rights and freedoms and the elimination of possible obstacles to their full or proper exercise.

Thus, in the theory of state and law, the main focus is on the guarantees of the realization and protection of human and citizen rights and freedoms, since the protection of individual rights is the key to the development of a democratic state.

\footnotetext{
${ }^{4}$ Marchenko M.N. (2002) Obshchaya teoriya gosudarstva i prava [General Theory of State and Law]. Akademicheskiy kurs: v 3 t, t. 3. 2-e izd., pererab. i dop. Moskva: Zertsalo-M, P. 77.

${ }^{5}$ Rabinovych P.M. (2002) Osnovy zaghaljnoji teoriji prava ta derzhavy [Fundamentals of the general theory of law and state]: navch. posib. 6-e vyd. Kharkiv: Konsum, pp. 116-117.

${ }^{6}$ Maghnovsjkyj I. (2002) Vidobrazhennja gharantij prav i svobod ljudyny ta ghromadjanyna u poghljadakh M. Draghomanova i M. Kovalevsjkogho [Reflection of guarantees of human and citizen rights and freedoms in the views of M. Drahomanov and M. Kovalevskyi]. Pravo Ukrajiny, no. 5, pp. 137-139.

${ }^{7}$ Kotjuk V.O. (2005) Zaghaljna teorija derzhavy i prava [General theory of state and law]: navch. posib. Kyjiv: Atika, P. 382.

8 Oborotov Yu.M. (1998) Suchasna derzhava: osnovy teoriji [The modern state: the foundations of theory]: navch. kurs. Odesa: Astroprynt, pp. 86-87.

${ }^{9}$ Shemshuchenko Ju. S. (ed.) Jurydychna encyklopedija [Legal Encyclopedia]: v 6 t., t. 1 : A-Gh. K. : Ukr. encykl. im. M. p. Bazhana, 1998, pp. 555.
} 
In civil law, a guarantee is understood as a caution, security, pledge, a condition that protects and secures ${ }^{10}$. A guarantee in civil law is a way of securing civil obligations, relationships between the parties and the special entity.

The problems of guarantees in labour law have been investigated in the works of such scientists as: N. Bolotina, V. Rudyk, S. Syvak, V. Skobielkin, B. Stashkiv and others ${ }^{11}$. In particular, the most thoroughly analyzed are the problems of regulatory guarantee as a specific legal means of securing, implementing, safeguarding and protecting labour rights.

Investigating the content of the administrative and legal support of human and citizen rights and freedoms, I. Yerusalimova, I. Yerusalimov, P. Pavlik, J. Udovenko call it an integral guarantee, that is the legal means which safeguard and protect the rights of citizens, suspend and eliminate violations, provide opportunities for their renewal ${ }^{12}$.

In addition, it should be noted that in legal science, the content of guarantees is often limited to the protection of legal norms, in particular, the reduction of guarantees to sanctions, the establishment of liability for their violation. However, if this principle is applied to other areas of law, especially those characterized by the regulation of public relations through prohibitions, this approach is correct. However, it seems rather limited, for example, for constitutional law. The specificity of the method of legal regulation of constitutional law is determined by the social function of this branch of law, which is characterized by the ability to guarantee the existence of certain social phenomena in reality.

Considering the state of development of state system guarantees as a relatively independent problem, it is worth noting that it is at the initial stage of the study and has not been comprehensively studied. Until now, only certain parts of the state legal sphere have been objects of guarantee. In the scientific literature there are no studies on the state system guarantees. In particular, one can cite examples of the following types of guarantees being successfully researched and explored in science: "guarantees of direct democracy", "guarantees of freedom of choice of representative bodies of

${ }^{10}$ Dal' V. (1955) Tolkovyy slovar' zhivogo velikorusskogo yazika [The Explanatory Dictionary of the Living Great Russian Language]: v 4 t. Moskva: Rus. yaz.,. T. 1, P. 344.

11 Rudyk V. (2005) Pro problemni pytannja normatyvnogho gharantuvannja prava na socialjnyj zakhyst [On the problematic issues of regulatory guarantee of the right to social protection]. Pidpryjemnyctvo, ghospodarstvo i pravo, no. 9, P. 37.

12 Ijerusalimova I.O., Ijerusalimov I.O., Pavlik P.M., Udovenko Zh.V. (2007) Administratyvno-pravove zabezpechennja prav i svobod ljudyny i ghromadjanyna [Administrative and legal support of human and citizen's rights and freedoms]: navch. posib. Kyjiv: Znannja. 
power" and "guarantees of elections". Exploring the reality of direct democracy, G. Murashyn identified guarantees of both the imposition of responsibility and the enforcement of coercive sanctions against violators of constitutional norms and principles, relevant provisions of other legislative acts aimed at protecting democratic foundations of life ${ }^{13}$.

The greatest attention was paid to the "guarantees of human and citizen rights and freedoms", which, for example, are described by A. Kolodii and A. Oliinyk as a system of norms-principles, conditions and means that ensure, in their totality, the exercise of constitutional rights, freedoms and legitimate interests of human beings and citizens ${ }^{14}$. The effectiveness of this system depends on various factors, the main among which is the presence of specific elements in the system of functioning of state power ${ }^{15}$. The guarantees make the necessary transition from the legal possibility to the actual exercise of rights and freedoms. For this reason, general guarantees are understood in the literature as those which encompass the totality of objective and subjective factors aimed at eliminating possible causes and obstacles to their improper implementation. And special (legal) guarantees are interpreted as legal means and methods by which the rights and freedoms of a person are realized, safeguarded and protected, and the violated rights are eliminated or renewed $^{16}$. The literature states that, on the whole, scholars are unanimous in their belief that the system of guarantees of human and citizen rights and freedoms includes the economic, political, social, moral, international, organizational and legal prerequisites necessary for securing and effective implementing, and comprehensive safeguarding of rights and freedoms of the individual, as well as the mechanism of their protection ${ }^{17}$. In monographs and other doctrinal studies a comprehensive analysis of the institute of constitutional rights and freedoms of man and citizen and problems of their guaranteeing has been made. The unity of approaches is that in the general

${ }^{13}$ Murashyn Gh.O. (2001) Gharantiji bezposerednjoji demokratiji [Guarantees of direct democracy]. Konstytucijno-pravovi formy bezposerednjoji demokratiji v Ukrajini: problemy teoriji i praktyky. Do 10-ji richnyci nezalezhnosti Ukrajiny. Kyjiv: In-t derzhavy i prava im. V.M. Korecjkogho NAN Ukrajiny, pp. 328-352

${ }^{14}$ Kolodij A.M., Olijnyk A.Yu. (2003) Prava ljudyny i ghromadjanyna [Human and citizen rights]: navch. posib. Kyjiv: Jurinkom Inter, P. 223.

${ }^{15}$ Olijnyk A.Yu. (2008) Konstytucijno-pravovyj mekhanizm zabezpechennja osnovnykh svobod ljudyny i ghromadjanyna v Ukrajini [The constitutional and legal mechanism for ensuring the fundamental freedoms of man and citizen in Ukraine]: monoghrafija. Kyjiv: Alerta; KNT; Centr navchaljnoji literatury, P. 157.

${ }^{16}$ Bessonova M., Birjukov O., S. Bondaruk (ed.) (2002) Osnovy demokratiji [Fundamentals of democracy]: navch. posib. dlja stud. vyshh. navch. zakl. Kyjiv: Aj Bi, P. 179.

${ }^{17}$ Zavorotchenko T. (2002) Systema konstytucijno-pravovykh gharantij i svobod ljudyny i ghromadjanyna v Ukrajini [The system of constitutional legal guarantees and freedoms of human and citizen in Ukraine]. Pravo Ukrajiny, no. 5, P. 110. 
form guarantees are characterized as rules, conditions, means and methods that ensure the effective implementation of the statutory capacity of human and citizen.

The general theoretical guarantee can be defined as a certain phenomenon that ensures a concrete positive result.

Terminological ambiguity in the sphere of state system guaranteeing in terms of its democratic modification adversely affects both the development of legal doctrine and the practice of state formation.

All social conditions, factors, phenomena that are part of the process of formation of the Ukrainian state system, which affect it, create a social background (environment), are considered for the subject of their guaranteeing power through the legal prism and legal "equivalent", through those criteria produced by the legal science, which allow us to distinguish the general prerequisites of reality, the state system guaranteeing from the actual guarantees of its implementation in the aspect of ensuring democracy and stability.

Scientific elaboration of this problem allows to define the Ukrainian state system guarantees as a system of general conditions and special (normativelegal and organizational-legal) means that ensure the existence and effectiveness of institutions of the state system.

The state system guarantees serve as a basis for the formation of certain social relations that have a common specificity. This allows them to be grouped together and characterized by distinguishing common features that are inherent in state system guarantees in general.

I would like to emphasise that in socio-political science the term "guarantees" is often used when it comes to principles. N. Bobrova explains this with the ambiguity of the term "guarantee", the authority and validity of its perception by citizens ${ }^{18}$. In legal science, the use of the term "guarantees" in the sense of prerequisites is unjustified. To designate general social guarantees a special term "principles" was created by jurisprudence.

Appeal to the principles (foundations, prerequisites) in the study of guarantees is explained, in addition, by the tendency of generalized coverage of guarantees of complex state-legal phenomena. "General guarantees" must be viewed through the prism of their true and probable anchorage, and differentiated with respect to the guaranteed object.

Hereafter, we will consider the basic features inherent in the Ukrainian state system guarantees.

1. Formal certainty. The state system guarantees, first of all, are enshrined in the Constitution and legislation of Ukraine. The role of the Constitution and

${ }^{18}$ Bobrova N.A. (1984) Garantii realizatsii gosudarstvenno-pravovykh norm [Guarantees of implementation of state legal norms]. Voronezh: Izd-vo Voronezh. un-ta, P. 28. 
laws of Ukraine in the state system guaranteeing is recognized by many researchers. Moreover, in a number of works it is pointed out that the Constitution (as a normative legal act of the highest legal force) is not only a guarantee of the stability of the state system, but also in general, is a condition for its existence ${ }^{19}$.

2. Systematicity. The systematicity of state system guarantees is determined, first of all, by the principle of systematicity of law. Systematicity of law, in turn, is a manifestation of social processes. The system of law in action is the interoperability of its individual elements, where the effectiveness of the whole chain of guaranteeing depends on the individual link, since the interconnection of phenomena helps to understand their essence more deeply. The system of state system guarantees can vary (for example, the range of subjects - government guarantors may be narrowed or expanded). However, the existence of these guarantees is a necessary consequence of the existence and formation of a state system of a certain type.

3. Purposefulness. First of all, ensuring any relationship or process is the basis of the concept of guarantees. This feature makes it possible to distinguish this legal phenomenon from others, such as subjective law, legal obligation, to single it out into an independent category, if the legal phenomenon does not ensure the achievement of the purpose, which is set in a certain phenomenon, it cannot be considered a guarantee ${ }^{20}$. In addition, the guarantee cannot exist as an independent phenomenon, regardless of the specific object, because the securing process always involves the presence of the object.

4. Procedurality. The realization of the goal set out in the guarantees implies the existence of procedural actions without which it is impossible to achieve a positive result. State system guarantees are largely determined by the behavior and activities of the subjects concerned. Therefore, when determining the state system guarantees, first of all, it must be assumed that they in any case have the subject of the activities of the relevant subjects. The subjects that ensure the sustainable functioning and development of the state system include: the Verkhovna Rada of Ukraine, the President of Ukraine, the Cabinet of Ministers of Ukraine, citizens of Ukraine, state-owned enterprises, institutions, organizations and more. Their activities are aimed at guaranteeing the rule of law.

5. Materiality. This feature is characterized by the fact that the state system guarantees are contained and enshrined in the norms of law, embodied in the acts of enforcement. Mandatory prerequisites for the possible and

${ }^{19}$ Poghorilko V.F. (1997) Osnovy konstytucijnogho ladu Ukrajiny [Fundamentals of the constitutional system of Ukraine]. Kyjiv: In Jure, P. 95.

${ }^{20}$ Skobelkin V.N. (1969) Yuridicheskie garantii trudovykh prav rabochikh i sluzhashchikh [Legal guarantees of labour rights of workers and employees]. Moskva: Nauka, P. 10. 
proper conduct of persons exercising power are legal acts that determine the conditions under which certain persons acquire a specific subjective right and have an appropriate legal obligation.

6. The permanent nature of the guarantees and the determination of the powers of the guarantor subjects. That is, the existence of actions or events with which the rules of law are associated with the occurrence of legal consequences, indicates the period of validity of guarantees, and in accordance with the constitutional principle of organization and activity of public authorities, we have a clear determination of their powers. For example, in the activity of such a subject of the state system as the Verkhovna Rada of Ukraine, the functioning of the guaranteeing mechanism begins after the occurrence of legal facts that determine the conditions for acquiring parliamentary powers, and ends with the termination of powers of the deputy, that is, the end of certain events and actions (sessions, meetings, etc.) or the attainment of a goal stipulated in the rule of law on the possible or proper conduct of a deputy, etc.

7. Effectiveness. The effectiveness of a legal phenomenon has traditionally been defined as the ratio between the actual result of the action of legal norms and those social goals to achieve which these norms were adopted $^{21}$. The research area is the most complex criteria for measuring performance, diffusion, systemic action and counteraction. It is virtually nondimensional, such as quantitative indicators of economic or legal effectiveness. It is difficult to apply the methods of specific sociology together with all the criteria for its measurement. Another feature of the effectiveness of state system guarantees is that it always has a political side associated with the development of democracy, the rule of law, and therefore it must be evaluated no less than the achievement of results in the economic sphere.

Indicators of the effectiveness of state system guarantees are both the qualitative state of the norms of the Constitution and other normative legal acts, as well as the mechanism of ensuring their implementation in social reality.

8. Adequacy of guarantees (orientation to the real level of development of public relations). The norms that correspond to the level of development of social relations, consistent with the system of law can be guaranteed.

The specificity of their legal nature is influenced by the implementation of the rules guaranteeing the state system order. They are an important constituent of the Constitution, have a high level of normative generalizations, have a special content and in a concentrated form fix the basic provisions on the organization and functioning of the state and its institutions.

${ }^{21}$ Bobrova N.A., Zrazhevskaya T.D. Otvetstvennost' v sisteme garantiy konstitutsionnykh norm (gosudarstvenno-pravovye aspekty) [Responsibility in the system of guarantees of constitutional norms (state and legal aspects)]. Voronezh: Izd-vo Voronezh. un-ta, 1985, pp. 124-126. 
The unity of the distinguished features characterizes the mechanism of guaranteeing state system, which ensures the smooth and efficient functioning of both the whole state mechanism and the state as a whole.

\section{State system guarantees: classification criteria and types}

The classification of guarantees is to some extent derived from the classification of the asset being guaranteed. Just as the choice of means to achieve any goal depends on the goal itself, so are the state system guarantees due to certain objects in need of guarantee. The derivation of classification criteria and relatively independent types of state system guarantees is based on the analysis of ideas, theories, doctrines and is conditioned by the historical, legislative, national and other features of the development of this institute.

Various classification criteria can be based on the classification of state system guarantees: the form of securing guarantees; the scope of the guarantees; the degree of their state security; the nature of the legal rules governing the state system; the relationship between the state and the citizen and other criteria. Depending on this, different approaches can be devised to divide state system guarantees into groups.

Traditionally, both in the theory of state and law, and in constitutional law, depending on the content and type of social activity, it is customary to allocate general and special (legal) guarantees.

General (social) guarantees are a set of objective and subjective factors that are aimed at practical implementation and comprehensive protection, elimination of possible causes and obstacles to the formation of a democratic state system in Ukraine. It is expedient to divide the general state system guarantee by the spheres of the state system into economic, political, social, ideological and cultural (spiritual).

It is worth noting that the economic state system guarantees are regulated by the Constitution and other normative legal acts of Ukraine, economic conditions and possibilities of implementation of the constitutional and legal regulations, the ability of the society and the state to provide the necessary material and financial resources for establishing a democratic state system in Ukraine. Economic guarantees are important in the system of state system guarantees, because they provide for the availability of appropriate environment and material basis for the stable functioning of the state.

Political guarantees of the state system are the system of democracy, appropriately oriented state policy, provided by the Constitution and other normative legal acts of Ukraine, aimed at democratization of the Ukrainian state system as a set of state and non-state institutions that exercise power, control of the society, ethnic and other groups, provide stability in the society, the corresponding order in it. Political guarantees of the state system are a set 
of political factors that ensure the promotion of a democratic legal regime in the country.

Social guarantees of the state system are a set of social conditions created and secured by the state, a system of social relations, unimpeded and free functioning of the institutions of a developed civil society, the state and the individual, the prevention of crisis phenomena in society and deepening the content of the legal status of a renewed state with a democratic state system based on the principles of humanism, justice, equality, and the expansion of real conditions in realizing the capabilities of each individual.

Social guarantees include a qualitatively new form of civic life that demonstrates a completely different relation between society, state and personality, its relation to other personalities and to itself ${ }^{22}$.

Economic, political and social guarantees create a set of conditions that ensures the development of the Ukrainian state system in a new vector of democratization and approximation to world standards.

Ideological guarantees of the state system are state-guaranteed ideological diversity, inadmissibility of recognition of any ideology obligatory by the state, prohibition of censorship, a system of moral and legal representations of personality. The ideological guarantees of the state system are the system of worldviews of the individual, which does not separate himself from the state. Such guarantees include the general and legal culture of society, ideological pluralism, the prohibition of the monopolization of ideology, democratic public opinion, and the like. These guarantees also include the activities of the state, its bodies, officials, local self-government bodies and society as a whole in the legal education of the population, which allows a person to participate more competently in making important socially important decisions.

The cultural (spiritual) guarantees of the state system are the system of cultural and spiritual values of the individual, proper cultural and educational level of the state, consolidation and development of the Ukrainian nation, its historical consciousness, traditions and culture. They are determined by the cultural function of the state and the existing systems of education, science, culture, art, information in the state and by the stable historical traditions in the sphere of cultural development of the state.

All, both general and special (legal) guarantees work in combination. General guarantees in general influence, create the basis for the existence of a democratic state system. But, even if such a system of guarantees is in place, its practical implementation is ensured, above all, by effective organizational activity.

${ }^{22}$ Zavorotchenko T. (2002) Systema konstytucijno-pravovykh gharantij i svobod ljudyny i ghromadjanyna $v$ Ukrajini [The system of constitutional legal guarantees and freedoms of human and citizen in Ukraine]. Pravo Ukrajiny, no. 5, pp. 112. 
In the process of forming the rule of law, the role of special (legal) guarantees of the state system - legal forms, means and methods by which the activity of the state in general and the activity of public authorities in particular are implemented, safeguarded and protected, deficiencies are eliminated and responsibility is established for violation of the current legislation, which ensures the existence of a democratic state system - is significantly increasing.

The peculiarity of special guarantees is that they directly ensure the lawfulness of the behaviour of the subjects of public relations, so special (legal) guarantees are a system of interrelated forms, means (regulatory, institutional and procedural) and methods that ensure the existence, effectiveness and the security of public institutions.

Special (legal) guarantees can be divided into two groups: normative-legal and organizational-legal, which form a unity, which is special organizationallegal guaranteeing.

Among the guarantees of the Ukrainian state system, the most important are the normative-legal guarantees. Normative-legal state system guarantees are a system of legal norms by which the functioning, safeguarding and protection of the Ukrainian state system are ensured. These include the guarantees enshrined in the Constitution of Ukraine and other legal acts. From the point of view of the broad approach, the normative-legal guarantees of the state system are a complex of legal norms and means by which the democratic nature of the state system, its safeguarding and protection are ensured. Depending on the form of objectification, the normative-legal guarantees of the state system are divided into: 1) constitutional; 2) sectoral (criminal, administrative, civil, criminal-procedural, administrative-procedural, etc.).

Constitutional guarantees are a set of rules and legal mechanisms established by the Basic Law, which are the basis for guaranteeing the stability and democracy of the functioning of the state system. It is important to emphasise that constitutional guarantees are of great importance, since it is the Constitution that determines the state system, the order of formation of state bodies and their system, and in general terms their competence. It is the system of constitutional guarantees that attests to the reality of the state system, which is especially important for ensuring its effectiveness.

Sectoral guarantees are the legal norms of the relevant branches of law (administrative, civil, family, criminal, etc.), which establish the legal means, forms and methods of the state system. These guarantees are also of considerable importance, since they guarantee the regulation at the legislative level of any public relations in the sphere of securing the formation of a state system. 
Let us take a closer look at the above types of guarantees.

V. Pogorilko defined constitutional guarantees as a type of legal guarantees, a mechanism for ensuring the observance, implementation, application and use of constitutional and other norms of law by state authorities, local self-government, their officials, other individuals and legal entities $^{23}$. Constitutional guarantees have the highest legal force and are the basis of legal guarantees. Constitutional guarantees in the narrow sense are guarantees regarding the Constitution of Ukraine itself as a normative legal act. In a broad sense, the constitutional guarantees are aimed at protecting the state and public order, rights, freedoms and responsibilities of man and citizen, forms of direct democracy, the President of Ukraine, bodies of legislative, executive and judicial power, institutions of local self-government, territorial structure of Ukraine, etc. Yu. Todyk, V. Zhuravskiy note that constitutional guarantees are the means, methods and mechanisms stipulated by the Fundamental Law of Ukraine that ensure the realization of a certain institute ${ }^{24}$.

Guaranteeing the Ukrainian state system consists in establishing its own status of the Constitution and, accordingly, the status of those institutions which it secures: in limiting the possibilities of introducing changes and additions to it, ie providing the Constitution with its own stability, as well as in regulating its order of definition, protection, functioning and changes in the Ukrainian state system.

The Constitution of Ukraine has the highest legal force, defines the status of state and non-state institutions that act as guarantors of the implementation of the constitutional rules on the Ukrainian state system, which results in the functioning of the respective constitutional order. Therefore, an important guarantee of the rule of law is the stability of the Constitution. Such stability is ensured by the difficult conditions envisaged in the Constitution regarding the procedure for introducing amendments to those parts which set the foundations of the state system.

Thus, the normative legal guarantee of the state system is ensured: first, by the Constitution of Ukraine; secondly, the whole system of current legislation of Ukraine: constitutional, administrative, informational, criminal, customs, etc. The list of guarantees offered is not exhaustive.

Normative-legal guarantees of the state system in terms of the content of regulatory influence can be divided into: 1) material guarantees - norms that establish both the basic and additional foundations of the state system

${ }^{23}$ Shemshuchenko Yu.S. (ed.) Jurydychna encyklopedija [Legal Encyclopedia]: v 6 t., t. 1 : A-Gh. K. : Ukr. encykl. im. M. p. Bazhana, 1998, pp. 554-555.

${ }^{24}$ Todyky Yu.M., Zhuravsjkogho V.S. (2002) Konstytucijne pravo Ukrajiny [Constitutional Law of Ukraine]: pidruchnyk. Kyjiv: In Jure, P. 167. 
(for example, norms-principles, which are enshrined in the Constitution of Ukraine and determine the principles of an all-Ukrainian referendum, principles of suffrage in elections to state bodies and local self-government, etc.); 2) procedural guarantees - norms that establish the legal obligations of public authorities (for example, regulate the procedure for preparing, organizing and holding a popular vote and the procedure for implementing its decisions, etc.); norms of law that establish the procedure for bringing to justice the violation of the principles of the state system.

Another group of special (legal) guarantees is organizational-legal guarantees. Organizational-legal (institutional) guarantees of the state system are a system of institutions (subjects) empowered to provide the implementation, safeguarding and protection of the main elements of the state system.

The analysis of the current Constitution of Ukraine gives sufficient reason to claim that it has enshrined a relatively complete system of organizational-legal guarantees of the state system. The following subjects are included in this system: the Ukrainian people, the state as a whole and represented by its respective bodies: the Verkhovna Rada of Ukraine, the President of Ukraine, the Cabinet of Ministers of Ukraine and other executive authorities, the courts of the judicial system, the Constitutional Court of Ukraine, the prosecutor's office and other supervisory bodies, as well as other subjects (political parties, public organizations, mass media, international bodies and organizations, etc.).

Organizational-legal guarantees of the state system can be classified according to the following criteria: 1 ) by the method of creating guarantors: state and non-state; 2) depending on the scope of action: domestic and international; 3) by nature of activity: bodies-guarantors of general competence and bodies-guarantors of special competence; 4) within the territory of the competence of the guarantor bodies: national and local; 5) by the functional purpose of the guarantor bodies: organizational-political, organizational-economic, organizational-social, organizational-cultural and organizational-ideological.

The guarantors of the state system may be state and non-state. The state as a whole, its respective bodies and institutes are the basic (main) guarantors of the state system, its stability and inviolability.

In the legal doctrine, state guarantors are called "principal" 25 . However, even in view of such an exceptional role of state institutions in guaranteeing the state system (for some of them, performing this function is a priority), it is noted in the literature that defining them as "principal" guarantors requires some

25 Poghorilko V.F. (1999) Zaghaljni zasady konstytucijnogho ladu Ukrajiny [General principles of the constitutional order of Ukraine] // Konstytucijne pravo Ukrajiny [Constitutional Law of Ukraine]: pidruchnyk / za red. V.Ya. Tacija, V.F. Poghorilka, Yu.M. Todyky. Kyjiv: Ukrajinsjkyj centr pravnychykh studij, pp. 100-101. 
clarification $^{26}$. In examining the state and public authorities as the main guarantors of the state system, it should be clearly understood that the exercise of this function is not aimed at ensuring the domination and restoration of a certain political regime or the realization of the interests of the ruling political elite, but only to preserve and further develop the democratic form of the state system.

In this sense, guaranteeing the state system, maintaining its stability and inviolability are a common goal of both the state and civil society. This emphasises the general vector of the development of the state, which should make every effort to promote the implementation of the principles founded by the constitution.

Non-state actors that are the guarantors of the state system are, for example, the media, who play an important role in leading the change of public consciousness. A democratic process is impossible without information sharing. This exchange of knowledge and information brings together the various levels of the state system and enables the institutions of power to perform the functions of governing the state and society. In this context, it should be noted that political information is important, that is, the information needed to make decisions in the sphere of public authority.

The activity of the guarantors of the state system is embodied in certain organizational-legal and procedural forms ${ }^{27}$. The guarantors of the state system should be regarded as the bearers of the complex of fundamental rights and freedoms, powers and responsibilities, which are intended to act within the limits and in the manner stipulated by law. The organizational form of legal personality of the guarantors of the state system was manifested through the recognition of them, in accordance with the Constitution and laws of Ukraine, of the rights and powers exercised through legal forms and means of activity (legal procedures).

The most important element of the organizational structure of the guarantors of the state system is the form of organization of public power. Organizational autonomy of public authorities lies in their exclusive rule, independence throughout Ukraine. Public authorities gain their status by creating them in the manner prescribed by the Constitution and other normative legal acts of Ukraine. The functions of public affairs management in the state are not subject to assignment by other organizations and communities, except for the bodies of power specified in the Constitution and

${ }^{26}$ Shymin Yu.V. (2003) Systema gharantij konstytucijnogho ladu: aktualjni pytannja teoriji i praktyky [The system of guarantees of the constitutional order: current questions of theory and practice]. Bjuletenj Ministerstva justyciji Ukrajiny, no. 11, pp. 93.

${ }^{27}$ Savchyn M. (1999) Konstytucijnyj Sud Ukrajiny u mekhanizmi gharantuvannja prav i svobod ljudyny [The Constitutional Court of Ukraine in the mechanism of guaranteeing human rights and freedoms]. Pravo Ukrajiny, no. 4, pp. 35-38. 
laws of Ukraine. The basis of public authority organization is to ensure coherence in society (the equal development of social groups).

A comprehensive and thorough analysis of the problem of scientific classification of state system guarantees allows to make the following generalizations. All guarantees are interdependent, complementary, and act as a single mechanism to ensure the stability and democracy of the Ukrainian state system. The system of state system guarantees - both general and special (legal) - is not exhaustive. It can and should be expanded, acquire the greatest effectiveness, clarity, purposefulness, while defending the basic democratic principles of the Ukrainian state system. State system guarantees can also be classified by other criteria.

In order to ensure the completeness of the consideration of the theory of state system guarantees, they can be classified by other criteria. Thus, depending on the nature of legal norms, the state system guarantees can be divided into material and procedural.

It should be emphasised that, as in the previous classification, material and procedural guarantees are closely interrelated, interdependent and interconnected, since procedural guarantees are a form of implementation of material guarantees. In terms of scope, state system guarantees are divided into domestic and international law.

Classification of these guarantees by other criteria is of great importance for the development of the theory of state system guarantees and their practical implementation. In particular, according to the subject of implementation we can distinguish the following guarantees: parliamentary, presidential, judicial, prosecutorial, administrative (managerial), controlling, etc. By the subject of guarantee, they can also be divided into: national guarantees, international guarantees and guarantees provided by the state with the participation of relevant associations of citizens (political parties, trade unions, etc.). By functional orientation, legal guarantees of the state system can be divided into: guarantees of implementation, guarantees of safeguarding, guarantees of protection. In the field of safeguarding and protection of the state system guarantees can be classified by the following objectives: 1) preventive (precautionary) guarantees, which are to prevent offences affecting the sustainable functioning of the Ukrainian state system; 2) preservative guarantees, aimed at the termination of detected offences that encroach on the state system; 3) punitive guarantees, aimed at the realization of the legal responsibility of offenders who encroach on the Ukrainian state system.

All the above classifications of state system guarantees are inherently logical and justified. The classification criteria are certain features of guarantees that do not fully reflect their content, nature and substance. To summarize, it should be noted that each of these groups of guarantees is at the 
forefront of the whole system of state system guarantees, and their interaction gives the greatest practical effect in the sphere of general requirements of the development of the democratic state system of Ukraine and strengthening of the rule of law.

\section{CONCLUSIONS}

The Ukrainian state system guarantees are a system of general conditions and special (normative-legal and organizational-legal) means that ensure the existence and effectiveness of institutions of the state system. State system guarantees are interconnected and interrelated, form the appropriate system and, in the aggregate, provide for its formation, comprehensive safeguarding and reliable protection. Signs of the state system guarantees are the following: formal certainty, systematicity, purposefulness, procedurality, materiality, permanent nature of the guarantees and determination of powers of the subjects of the state system, effectiveness, adequacy of guarantees (orientation to the real level of development of social relations).

Derivation of classification criteria and relatively independent types of guarantees of the state system is based on the analysis of ideas, theories, doctrines and is conditioned by the historical, legislative, national, political and other features of the development of this institution. Various classification criteria are based on the classification of guarantees. The scientific classification, taken as a basis, allows us to consistently explore the complex, multilevel and multifaceted mechanism of guaranteeing the state system, without violating the integrity of the criteria. The application of different classification models allows to obtain a comprehensive description of the system of state system guarantees, to understand the specifics of their practical implementation. Analysis of the state system guarantees from the standpoint of the systematic approach allows to distinguish the following classification criteria and types of state system guarantees: depending on the content and type of social activity: general and special (legal) guarantees. State system guarantees in the spheres of government are divided into: economic, political, social, ideological and cultural guarantees.

Special (legal) guarantees by way of security can be divided into two groups: normative-legal and organizational-legal guarantees. Normative-legal guarantees of the state system can be classified: by the content of regulatory influence on: material and procedural guarantees; by objectification form: constitutional and sectoral (criminal, administrative, civil, criminalprocedural, administrative-procedural, etc.) guarantees. In turn, organizational-legal guarantees of the state system should be classified according to the following criteria: by the method of creating guarantors: state and non-state; depending on the scope: domestic and international; by nature 
of activity: bodies-guarantors of general competence and bodies-guarantors of special competence; by territory of competence of guarantors: national and local; by functional purpose: organizational-political, organizationaleconomic, organizational-social, organizational-cultural and organizationalideological.

Classification of these guarantees by other criteria is also important for the development of the theory of state system guarantees and their practical implementation: by the subject of implementation: parliamentary, presidential, judicial, prosecutorial, administrative (managerial), controlling, etc.; by subject of guarantee: national, international and guarantees provided by the state with the participation of relevant associations of citizens (political parties, trade unions, etc.); by functional orientation: guarantees of implementation, guarantees of safeguarding, guarantees of protection; for the immediate purposes: preventive (precautionary), preservative, punitive.

\section{SUMMARY}

The paper deals with the problem of guaranteeing state system. It is determined that the actualization of ensuring the stability and efficiency of the state system is due to the fact that not all norms that guarantee the state system are implemented and have been embodied in actual social relations. This situation is explained by the crisis of transients that are taking place not only in the legal sphere, but also in the sphere of economy, politics, culture and social life. The transition period in the legal sphere is a relatively long process of instability, incompleteness, imbalance, characterized by the unstable nature of alternatives and options for development.

It is emphasised that the purpose of state system guarantees is to create the most favorable conditions for the functioning of its institutions, so that the democratic form of the state system is not only constitutionally proclaimed "de jure", but also unimpeded, effective and consistently implemented "de facto", That is, the possibility envisaged in the law would be turned into reality. An effective system of state system guarantees is a recognized measure of its reality.

Research into the etymology of the term "guarantee" and the analysis of scientific points of view on understanding the concept of state system guarantees made it possible to formulate a definition. The Ukrainian state system guarantees are a system of general conditions and special (normativelegal and organizational-legal) means that ensure the existence and effectiveness of institutions of the state system. The features of state system guarantees are the following: formal certainty, systematicity, purposefulness, procedurality, materiality, permanent nature of the guarantees and determination of powers of the subjects of the state system, effectiveness, 
adequacy of guarantees (orientation to the real level of development of social relations).

Derivation of classification criteria and relatively independent types of state system guarantees is based on the analysis of ideas, theories, doctrines, and is conditioned by the historical, legislative, national, political and other features of the development of this institution. Various classification criteria are based on the classification of guarantees. The scientific classification, taken as a basis, allows us to consistently explore the complex, multilevel and multifaceted mechanism of guaranteeing the state system without violating the integrity of the criteria.

\section{REFERENCES}

1. Nalyvajko L.R. (2005) Gharantiji derzhavnogho ladu Ukrajiny: problemy vyznachennja ponjattja [State system of Ukraine guarantees: problems of definition of the concept]. Naukovyj visnyk Jurydychnoji akademiji Ministerstva vnutrishnikh sprav, no. 4 (24), pp. 153-159 [in Ukrainian].

2. Nalyvajko L.R. (2009) Derzhavnyj lad Ukrajiny: teoretyko-pravova modelj [State system of Ukraine: theoretical and legal model]: monoghrafija. Kharkiv: Pravo [in Ukrainian].

3. Korel'skiy V.M., Perevalov V.D. (1998) Teoriya gosudarstva i prava [Theory of Government and Rights]: uchebnik. Moskva: Infra-M [in Russian].

4. Marchenko M.N. (ed.) (2002) Obshchaya teoriya gosudarstva i prava [General Theory of State and Law]. Akademicheskiy kurs: v 3 t, t. 3. 2-e izd., pererab. i dop. Moskva: Zertsalo-M, pp. 69-88 [in Russian].

5. Rabinovych P.M. (2002) Osnovy zaghaljnoji teoriji prava ta derzhavy [Fundamentals of the general theory of law and state]: navch. posib. 6-e vyd. Kharkiv: Konsum [in Ukrainian].

6. Maghnovsjkyj I. (2002) Vidobrazhennja gharantij prav i svobod ljudyny ta ghromadjanyna u poghljadakh M. Draghomanova i M. Kovalevsjkogho [Reflection of guarantees of human and citizen rights and freedoms in the views of M. Drahomanov and M. Kovalevskyi]. Pravo Ukrajiny, no. 5, pp. 137-139 [in Ukrainian].

7. Kotjuk V.O. (2005) Zaghaljna teorija derzhavy i prava [General theory of state and law]: navch. posib. Kyjiv: Atika [in Ukrainian].

8. Oborotov Yu.M. (1998) Suchasna derzhava: osnovy teoriji [The modern state: the foundations of theory]: navch. kurs. Odesa: Astroprynt [in Ukrainian].

9. Shemshuchenko Yu.S. (ed.) Jurydychna encyklopedija [Legal Encyclopedia]: v 6 t., t. 1 : A-Gh. K. : Ukr. encykl. im. M.P. Bazhana, 1998 [in Ukrainian]. 
10. Dal' V. (1955) Tolkovyy slovar' zhivogo velikorusskogo yazika [The Explanatory Dictionary of the Living Great Russian Language]: v 4 t. Moskva: Rus. yaz.,. T. 1 [in Russian].

11. Rudyk V. (2005) Pro problemni pytannja normatyvnogho gharantuvannja prava na socialjnyj zakhyst [On the problematic issues of regulatory guarantee of the right to social protection]. Pidpryjemnyctvo, ghospodarstvo i pravo, no. 9, pp. 37-39 [in Ukrainian].

12. Ijerusalimova I.O., Ijerusalimov I.O., Pavlik P.M., Udovenko Zh.V. (2007) Administratyvno-pravove zabezpechennja prav i svobod ljudyny i ghromadjanyna [Administrative and legal support of human and citizen's rights and freedoms]: navch. posib. Kyjiv: Znannja [in Ukrainian].

13. Murashyn Gh.O. (2001) Gharantiji bezposerednjoji demokratiji [Guarantees of direct democracy]. Konstytucijno-pravovi formy bezposerednjoji demokratiji v Ukrajini: problemy teoriji i praktyky. Do 10-ji richnyci nezalezhnosti Ukrajiny. Kyjiv: In-t derzhavy i prava im. V.M. Korecjkogho NAN Ukrajiny, pp. 328-352 [in Ukrainian].

14. Kolodij A.M., Olijnyk A.Yu. (2003) Prava ljudyny i ghromadjanyna [Human and citizen rights]: navch. posib. Kyjiv: Jurinkom Inter [in Ukrainian].

15. Olijnyk A.Yu. (2008) Konstytucijno-pravovyj mekhanizm zabezpechennja osnovnykh svobod ljudyny i ghromadjanyna v Ukrajini [The constitutional and legal mechanism for ensuring the fundamental freedoms of man and citizen in Ukraine]: monoghrafija. Kyjiv: Alerta; KNT; Centr navchaljnoji literatury [in Ukrainian].

16. Bessonova M., Birjukov O., Bondaruk S. (ed.) (2002) Osnovy demokratiji [Fundamentals of democracy]: navch. posib. dlja stud. vyshh. navch. zakl. Kyjiv: Aj Bi [in Ukrainian].

17. Zavorotchenko T. (2002) Systema konstytucijno-pravovykh gharantij i svobod ljudyny i ghromadjanyna v Ukrajini [The system of constitutional legal guarantees and freedoms of human and citizen in Ukraine]. Pravo Ukrajiny, no. 5, pp. 110-115 [in Ukrainian].

18. Bobrova N.A. (1984) Garantii realizatsii gosudarstvenno-pravovykh norm [Guarantees of implementation of state legal norms]. Voronezh: Izd-vo Voronezh. un-ta [in Russian].

19. Poghorilko V.F. (1997) Osnovy konstytucijnogho ladu Ukrajiny [Fundamentals of the constitutional system of Ukraine]. Kyjiv: In Jure [in Ukrainian].

20. Skobelkin V.N. (1969) Yuridicheskie garantii trudovykh prav rabochikh i sluzhashchikh [Legal guarantees of labour rights of workers and employees]. Moskva: Nauka [in Russian]. 
21. Bobrova N.A., Zrazhevskaya T.D. Otvetstvennost' v sisteme garantiy konstitutsionnykh norm (gosudarstvenno-pravovye aspekty) [Responsibility in the system of guarantees of constitutional norms (state and legal aspects)]. Voronezh: Izd-vo Voronezh. un-ta, 1985 [in Russian].

22. Todyky Yu.M., Zhuravsjkogho V.S. (2002) Konstytucijne pravo Ukrajiny [Constitutional Law of Ukraine]: pidruchnyk. Kyjiv: In Jure [in Ukrainian].

23. Poghorilko V.F. (1999) Zaghaljni zasady konstytucijnogho ladu Ukrajiny [General principles of the constitutional order of Ukraine] // Konstytucijne pravo Ukrajiny [Constitutional Law of Ukraine]: pidruchnyk / za red. V.Ya. Tacija, V.F. Poghorilka, Yu.M. Todyky. Kyjiv: Ukrajinsjkyj centr pravnychykh studij, pp. 63-103 [in Ukrainian].

24. Shymin Yu.V. (2003) Systema gharantij konstytucijnogho ladu: aktualjni pytannja teoriji i praktyky [The system of guarantees of the constitutional order: current questions of theory and practice]. Bjuletenj Ministerstva justyciji Ukrajiny, no. 11, pp. 86-96 [in Ukrainian].

25. Savchyn M. (1999) Konstytucijnyj Sud Ukrajiny u mekhanizmi gharantuvannja prav i svobod ljudyny [The Constitutional Court of Ukraine in the mechanism of guaranteeing human rights and freedoms]. Pravo Ukrajiny, no. 4, pp. 35-38 [in Ukrainian].

Information about the author:

Larysa Nalyvaiko,

Doctor of Law, Professor,

Honored Lawyer of Ukraine, Vice-Rector, Dnipropetrovsk State University of Internal Affairs

26, Gagarina Ave, Dnipro, Ukraine

ORCID ID: orcid.org/0000-0002-7696-4223 